\title{
KOMUNIKASI DAKWAH PENYULUH AGAMA ISLAM DALAM MEMBERIKAN PEMAHAMAN MODERASI BERAGAMA
}

\author{
Nadang Kusnandar \\ Koordinator Kerukunan Umat Beragama (KUB) \\ Kementerian Agama Kota Bandung Jawa Barat \\ Nadangkusnandar377@gmail.com
}

\begin{abstract}
This research was conducted in Ujungberung sub-district. This research is a qualitative research that emphasizes the phenomenological aspects of Islamic religious extension agents in Ujungberung District, Bandung City. The research method in this research is descriptive qualitative. The experience of Islamic Religious Instructors in Ujungberung District in carrying out counseling on religious moderation with various joys and getting deep knowledge in the field when carrying out counseling and also there are still people who do not know about extensionists themselves. And in carrying out extension services in Ujungberung District, it is inseparable from the main duties and functions of extension workers to carry out and develop guidance activities with the function of extension personnel as informative and educational, consultative and advocacy The Islamic Religious Instructor in delivering da'wah messages through tabligh in Ujungberung District reviews several aspects including: First, in terms of the form of activities carried out by Islamic religious extension agents in Ujungberung District, in accordance with the informative and educational function of the form of extension activities carried out, consisting of Majlis Taklim, MTKD, Training, Friday Sermons and Lectures. Second, in terms of the type of message conveyed in accordance with the form of extension activities carried out. The types of messages conveyed in the activity of conveying da'wah messages through tabligh include messages of Aqidah, Morals, Figh, and Love for the Fatherland or in other languages called Nationalism. Third, in terms of those used in conveying da'wah messages in extension activities. The media used by the extension agents consisted of print media, written media and electronic media. Ceta media consists of Al-Qur'an, Hadith books, religious books and other printed media such as leaflets or brochures.
\end{abstract}

Keywords: Da'wah Communication; Islamic Religious Instructor; Religious Moderation. 


\section{A. Latar Belakang}

Kota Bandung sebagai ibukota provinsi Jawa Barat dihadapkan pada berbagai permasalahan sosial kemasyarakatan. Masalah kebodohan, pengangguran, kemiskinan, kerusakan lingkungan hidup, kenakalan remaja dan aliran sempalan menjadi konsumsi rutin masyarakat. Untuk mengurai permasalahan yang ada, pemerintah kota Bandung mencanangkan beberapa program prioritas yang meliput bidang pendidikan, ekonomi, kesehatan, lingkungan hidup, olah raga, seni budaya dan agama. Bidang agama dijadikan sebagai ujung tombak pembangunan melalui program "Bandung Kota Agamis yang Juara".

Program Bandung Agamis merupakan implementasi dari visi Kota Bandung Juara, yang akan menjadikan Bandung kota yang nyaman, unggul dan sejahtera. Sesuai dengan kondisi penduduk kota Bandung yang dikenal sangat religius. Jumlah penduduknya 2.397.396 jiwa. Jumlah laki-laki 1.211.820 dan Perempuan 1.185.576 jiwa. Dari sisi pengataman Ulama 88,8\% umat Islam, 1\% katolik, 8,8\% Protestan, 0,5\% Hindu dan 0,9\% Budha. ${ }^{1}$

Pluralisme ini tercermin dari komposisi jumlah penduduk kecamatan Ujungberung dari 5 keluarahan yaitu kelurahan Pasir Endah, Cigending, Pasir wangi, Pasir Jati, dan Pasanggrahan pada bulan Februari tahun 2017 yang cukup signifikan, yaitu jumlah penduduk 30.026 jiwa terdiri dari 70.071 jiwa (beragama Islam), 754 jiwa (beragama Kristen), 327 jiwa (beragama Khatolik), 76 jiwa (beragama Hindu), 17 jiwa (beragama Budha), dan 2 jiwa (kepercayaan). (Laporan Kependudukan Bulan Februari Tahun 2017 Tingkat Kecamatan Ujungberung).

Ruang lingkup atau Kebijakan Pemerintah Kota Bandung mengenai Bandung Agamis Juara tertuang dalam tiga program yaitu 1) Program peningkatan pemahaman dan pengamalan agama; 2) Program pengembangan iklim religius lingkungan agamis dan aktifitas sosial keagamaan; 3) Program peningkatan toleransi kerukunan umat beragama. ${ }^{2}$

1“Data Kependudukan: Dinas Kependudukan dan Catatan Sipil Kota Bandung :Tahun 2016)." (DUKCAPIL KOTA BANDUNG, 2016).

2 Asep Muhtadi Saeful, Bandung Agamis Landasan, Pendekatan, Indikasi dan program Aksi, 1st ed., 1 (Sekretariat Daerah Kota Bandung, 2009), 34. 
Program peningkatan pemahaman dan pengamalan agama memiliki indikator peningkatan pendidikan keagamaan baik secara kuantitas maupun kualitas 3 . Secara kuantitas pemahaman agama kurang lebih jumlah para pembimbing keagamaan di masyarakat, sedangkan secara kualitas memiliki ilmu pengetahuan agama serta dapat menjadi rujukan umat. Program pengembangan iklim religius bertujuan mewujudkan lingkungan agamis dengan indikator keberhasilan meningkatnya kualitas lingkungan peribadatan, aktifitas keagamaan, kualitas sarana dan prasarana peribadatan serta tersedianya peta potensi keagamaan.

Indonesia sebagai negara yang memiliki penduduk muslim terbanyak di dunia menjadi sorotan penting dalam hal moderasi Islam. Moderasi adalah ajaran inti agama Islam. ${ }^{4}$ Islam moderat adalah paham keagamaan yang sangat relevan dalam konteks keberagaman dalam segala aspek, baik agama, adat istiadat, suku dan bangsa itu sendiri program peningkatan moderasi dan kerukunan umat beragama bertujuan untuk bertoleransi dalam kehidupan yang beragam agama dan penduduk dalam arti bertoleransi dalam kemajemukan penduduk yang ada di kota Bandung. Indikator dari program ini adalah meningkatnya pemahaman untuk mewujudkan kerukunan hidup antar pemeluk agama serta meningkatnya kerjasama antar pemeluk dan dengan pemerintah.

Untuk mewujudkan tiga program tersebut, diperlukan agen yang secara langsung terhubung dengan masyarakat Kota Bandung. Agen tersebut berperan melakukan sosialisasi program, membantu internalisasi pemahaman terhadap program, sampai tahap aplikasi program. Secara strategis, salah satu agen yang dapat melakukan tugas dan peran tersebut adalah tenaga keagamaan, baik pemuka agama, pembimbing agama, termasuk di dalamnya adalah penyuluh agama.

3 Husnul Khotimah, "INTERNALISASI MODERASI BERAGAMA DALAM KURIKULUM PESANTREN," Rabbani: Jurnal Pendidikan Agama Islam 1, no. 1 (January 27, 2020): 6, https:/ / doi.org/10.19105/rjpai.v1i1.3008.

4 Mohamad Fahri and Ahmad Zainuri, "Moderasi Beragama di Indonesia" 25, no. 2 (2019): 95, https://doi.org/DOI: doi.org/10.19109/intizar.v25i2.5640. 
Penyuluh Agama pada tataran praktiknya selalu dihadapkan pada dua persoalan yang problematis. Pertama, dihadapkan pada rasio kuantitas penyuluh agama yang tidak seimbang. Kedua, penyuluh agama mesti berhadapan dengan sikap masyarakat yang masih apatis terhadap keberadaan penyuluh agama.

Ajaran agama Islam di Indonesia, dilakukan dengan cara damai ${ }^{5}$, tidak memaksa penyuluh Agama Islam sebagai pelaksana kegiatan penyiaran dalam memberikan pemahaman tentang moderasi beragama mempunyai peranan yang sangat strategis. Karena berbicara masalah dakwah atau kepenyuluhan agama berarti berbicara masalah ummat dengan semua problematika. Sebab banyak kasus dan dari banyak fakta dakwah, tanda-tanda kemaslahatan ummat (jamaah) belum mampu diwujudkan oleh pelaksana dakwah (Penyuluh). Oleh karena itu, penyuluh mharus memahami betul fungsi dari penyuluh itu sendiri.

Permasalahan tersebut sangat terasa apabila bertemu dengan beberapa hal yang melekat pada peran dan fungsi penyuluh. Menurut Abdul Jamil, penyuluh agama Islam mempunyai tiga fungsi yaitu: pertama Fungsi Informatif dan Edukatif: Penyuluh agama Islam memposisikan sebagai da'i dalam arti luas yang berkewajiban menda'wahkan Islam. Kedua Fungsi Konsultatif: Penyuluh agama Islam menyediakan dirinya untuk turut memikirkan dan memecahkan persoalan-persoalan yang dihadapi masyarakat. Ketiga Fungsi Advokatif: Penyuluh agama Islam memiliki tanggung jawab moral dan sosial untuk melakukan kegiatan pembelaan terhadap umat atau masyarakat dari berbagai ancaman, gangguan, hambatan dan tantangan. ${ }^{6}$

5 Ahmad Agis Mubarok and Diaz Gandara Rustam, "ISLAM NUSANTARA: MODERASI ISLAM DI INDONESIA," Journal of Islamic Studies and Humanities, 2018, 155, https://doi.org/DOI: http:/ / dx.doi.org/10.21580/jish.32.3160.

6 Abdul Jamil, "Penyuluhan Agama Islam Dan Problema Keislaman Kontemporer," in SEMINAR (Seminar Penyuluhan Agama Islam. Semarang: LABDA Fakultas Dakwah Dan Komunikasi IAIN Walisongo, LABDA Fakultas Dakwah Dan Komunikasi IAIN Walisongo, n.d.), 4. 
Tugas dan fungsi pokok yang wajib dilaksanakan oleh penyuluh Agama Islam ${ }^{7}$ sebagaimana telah tercantum dan dijelaskan dalam Keputusan Direktur Jenderal Bimbingan Masyarakat Islam Nomor DJ.II/432 Tahun 2016, tentang Petunjuk Teknis Pengangkatan Penyuluh Agama Islam Non PNS bahwa yang terkait dengan tugas dan fungsi sebagai penyuluh agama, ada tiga fungsi pokok penyuluh agama Islam Nom PNS diantaranya, fungsi informatif, edukatif, konsultatif dan advokatif.

a. Fungsi informatif dan edukatif Penyuluh Agama adalah berkewajiban menyampaikan ajaran agama baik dalam bentuk ceramah, khutbah, tabligh dan pembinaan keagamaan dengan membentuk TPA (Taman Pendidikan Al-Qur'an) kepada masyarakat.

b. Fungsi konsultatif Penyuluh Agama adalah berkewajiban menjadi seorang konselor yang memberikan pembimbingan kepada masyarakat untuk menyelesaikan masalah-masalah keagamaan yang terjadi dilingkungan masyarakat.

c. Fungsi advokatif penyuluh agama tentu berkewajiban memberikan pembinaan dan pembimbingan yang bertujuan untuk membela dan melindungi masyarakat dari berbagai ancaman terhadap gangguan akidah, keimanan, ibadah dan akhlakul karimah masyarakat.

Ketiga fungsi diatas pada dasarnya berfungsi menawarkan solusi dalam setiap persoalan yang dihadapi kelompok masyarakat dan memberikan pembelaan kepada masyarakat dalam menjalankan nilai-nilai ajaran agana Islam di masyarakat mengalami hambatan dan kendala. ${ }^{8}$

Berpijak pada persoalan di atas, tentu komunikasi dakwah penyuluh agama dalam menyampaikan pesan keagamaan untuk mewujudkan "Bandung Agamis" yang Juara. Mengingat kondisi sosial keagamaan di Ujungberung yang plural, kuantitas penyuluh yang relatif minim dan masyarakat yang cenderung bersikap apatis terhadap kebijakan pemerintah. Padahal pada

7 “Https://Www.Republika.Co.Id/Berita/Dunia-Islam/IslamNusantara/19/05/20/Prscm7320-Pentingnya-Memaksimalkan-4Tugas-Pokok-Penyuluh-Agama," n.d.

${ }^{8}$ Ahmad Mubarok, Konseling Agama: Teori dan kasus, 1st ed., vol. 1 (JAKARTA: PT Bina Rena Parwira, 2002), 2. 
satu sisi peran dan fungsi Penyuluh Agama merupakan ujung tombak untuk mewujudkan kebajikan pemerintah. Oleh sebab itu, penelitian tentang Komunikasi Dakwah Penyuluh Agama Islam Dalam Memberikan Pemahaman Moderasi Beragama Di Kecamatan Ujungberung Kota Bandung Jawa Barat. Penelitian ini bermaksud menguraikan manajemen Pelaksana teknis dalam menjalankan peran dan fungsi penyuluh untuk mendukung Program Bandung Agamis yang Juara.

\section{B. Metode Penelitian}

Kajian mengenai komunikasi dakwah penyuluh ini, pada akhirnya memiliki konsekuensi metodologi. Sehingga pada metodologi membahas mengenai metodologi penelitian yang digunakan dalam penelitian ini. Metodologi merupakan suatu implikasi logis, nilai-nilai, asumsi-asumsi, aturan-aturan, dan kriteria yang menjadi bagian tak terpisahkan dalam suatu penelitian. Oleh karena itu, posisi metodologi dipandang sebagai suatu penegas. Paradigma penelitian yang digunakan dalam penelitian ini adalah dengan menggunakan Sesuai dengan sifat dan karakter permasalahan data yang diangkat dalam penelitian ini, maka dalam penelitian ini menggunakan paradigma interpretif, menurut Morissan paradigma interpretatif merupakan paradigma yang dilakukan dengan menginterprestasikan karya seni berdasarkan sudut pandang pengamat, baik dari kesamaan pengalaman, unsur estetis, dan pengetahuan yang dimiliki oleh pengamat. ${ }^{9}$

Oleh karena itu, terkait dengan penelitian ini fokus pada penelitian ini dipandangn tepat digunakan, karena bertujuan untuk mengetahui secara subjektif bentuk-bentuk komunikasi dari segi pengalaman, penyampaian pesan dakwah dan interaksi Penyuluh Agama Islam di Kecamatan Ujungberung dengan masyarakat setempat. Dalam proses penelitian disini akan menggunakan jenis penelitian kualitatif deskriptif. penelitian kualitatif, yakni prosedur data penelitian yang dikumpulkan dalam bentuk data deskriptif berupa kata-kata dan gambar yang tertulis atau lisan dari perilaku orang-orang yang diamati, data

9 "Paradigma Interpretatif.Htm," n.d., di akses pada tanggal 15-09 2020. 
tersebut meliputi interview, observasi dan dokumen terkait.10 Metode penelitian dalam rencana penelitian ini akan menggunakan Naturalistik. Naturalistik karena penelitannya dilakukan pada kondisi yang alamiah (natural setting), penelitian yang dilakukan pada objek yang alamiah yakni objek yang berkembang apa adanya, tidak dimanipulasi oleh peneliti. ${ }^{11}$

Sumber data dalam penelitian ini diperoleh dari anggota penyuluh agama Islam di kecamatan ujung berung dan memiliki pengalam-pengalaman disaat melakukan penyuluhan kepada masyarakat. Pada saat kegiatan penelitian berlangsung dalam persoalan ini, yang dilakukan terkait dengan kegiatan ini adalah bertanya, mengamati dan mendengar sehingga, data yang didapatkan murni data pokok sesuai dengan apa yang dibutukan dalam penelitian ini.

\section{Hasil Dan Pembahasan}

\section{Kondisi Objektif KUA Kecamatan Ujungberung}

Identitas nama kantornya KUA Kecamatan Ujungberung. KUA ini mulai diresmikan berdiri sejak tahun 1991. Luas wilayah kantor KUA Kecamatan Ujungberung menurut data dari hasil observasi $165 \mathrm{~m}^{2}$ yang terdiri dari Luas Bangunan $90 \mathrm{~m}^{2}$, dan Luas Halaman $75 \mathrm{~m}^{2}$. Kantor KUA Kecamatan Uungberung memiliki 7 jumlah ruangan.

Secara administrasi KUA Kecamatan Ujungberung berada di Jl. Alun - alun barat No. 183. Kelurahan Cigending, Kecamatan Ujungberung, Kota Bandung, Propinsi Jawa Barat, Kode Pos 40611, Telepon (022) 7832098.12

\section{a. Visi dan Misi}

Adapun Visi dari Penyuluh Agama Islam Kantor Urusan Agama Kecamatan Ujungberung adalah Memberdayakan sumber daya dan kemampuan serta potensi diri KUA dalam memberikan pelayanan prima di bidang agama agar terwujud masyarakat

10 Asmadi Alsa, Penelitian Psikologi, II (Yogyakarta: Pustaka Pelajar Offset, 2004), 12.

11 Sugiyono, Metode Penelitian Pendidikan; Pendekatan Kuantitatif, Kualitatif, Dan RED, III (Bandung: Alfabeta, 2010), 15.

12 "Profil Laporan Tahunan KUA Ujungburung, Tahun 2016." (KUA Ujungberung, 2016). 
Kecamatan Ujungberung yang agamis. Untuk mengimplementasikan visi yang telah ditetapkan, maka misi Penyuluh Agama Islam Kantor Urusan Agama Kecamatan Ujungberung Kota Bandung adalah meningkatkan pemahaman nilai spiritual dan etika keagamaan melalui:

a. Penertiban administrasi keagamaan secara komprehensif.

b. Peningkatan kualitas pelayanan prima di bidang urusan agama Islam.

c. Memperkokoh kerukunan antar umat beragama menuju masyarakat madani.

d. Peningkatan kualitas bimbingan pelayanan, pembinaan kepenghuluan dan keluarga sakinah.

e. Peningkatan pembinaan kemasjidan, ibadah sosial dan produk halal

f. Peningkatan pembinaan dan penyuluhan ibadah haji

g. Peningkatan pembinaan pendidikan keagamaan di masyarakat

\section{Pengalaman Penyuluh Agama Islam di Kecamatan Ujungberung Kota Bandung dalam Melaksanakan Penyuluhan}

Tugas penyuluh agama Islam sekarang ini berhadapan dengan suatu kondisi masyarakat yang berubah dengan cepat yang mengarah pada masyarakat fungsional, masyarakat teknologis, masyarakat saintifik dan masyarakat terbuka. Dengan demikian, setiap penyuluh agama secara terus menerus perlu meningkatkan pengetahuan, wawasan dan pengembangan diri, dan juga perlu memahami visi penyuluh agama serta menguasai secara optimal terhadap materi penyuluhan agama itu sendiri maupun teknik menyampaikannya. Sehingga ada korelasi faktual terhadap kebutuhan masyarakat pada setiap gerak dan langkah mereka. ${ }^{13}$

Keberhasilan seorang Penyuluh Agama Islam dalam melaksanakan tugasnya di masyarakat dipengaruhi oleh beberapa komponen diantaranya komponen strategi dakwah yang dipilih dan dirumuskan. Karena kemajemukan masyarakat

13 Bob Andrian, "KOMUNIKASI KONSULTATIF PENYULUH AGAMA ISLAM DI DAERAH PERBATASAN KALIMANTAN BARAT," Jurnal Bimbingan Penyuluhan Islam 1, no. 2 (January 11, 2020): 254-55, https://doi.org/10.32332/jbpi.v1i2.1717. 
Indonesia yang terdiri dari berbagai suku, ras, tradisi, bahasa, serta status sosial ekonomi yang berbeda-beda. Menghadapi kondisi ini seorang penyuluh harus menyusun strategi yang tepat dalam pelaksanaan tugas kepenyuluhannya demi tercapainya tujuan tugas itu. ${ }^{14}$ Disamping itu materi penyuluhan tergantung pada tujuan yang hendak dicapai, namun secara global dapatlah dikatakan bahwa materi penyuluhan dapat diklasifikasikan menjadi tiga hal pokok, yaitu " masalah keimanan (aqidah), masalah keislaman (syari ah) dan masalah budi pekerti (akhlakul karimah)".

Adapun pengalama para Penyuluh Agama Islam dalam melaksanakan penyuluhan di Kecamatan Ujungberung dengan berbagai ragam pengalama. Sebagaimana hasil penelitian dilapangan dan hasil wawancara dengan para penyuluh diantaranya:

Menurut Bapak RA Qudus pengalaman dalam melaksanakan penyuluhan mengatakan bahwa:

“selama 17 tahun saya diangkat jadi penyuluh pengalaman saya pak nandang penyuluhan di Ujungberung banyak suka dukanya, karena masyarakat yang heterogen sehingga penyuluhan berjalan dengan baik, mereka menerima penyuluh di Majlis Taklim dengan antusias. Apalagi bila penyuluh memberikan materi yang menarik."15

Berbeda dengan pengalaman Bapak Fahmi Ayatulloh dalam melaksanakan penyuluhan di Kecamatan Ujungberung, mengatakan bahwa:

“pengalaman saya selama diangkat 8 Tahun diangkat menjadi penyuluh dalam melaksanakan penyuluhan tidak terlepas dari tugas pokok dan fungsi penyuluh untuk melaksanakan dan mengembangkan kegiatan bimbingan dengan fungsi penyuluh sebagai informatif dan edukatif, konsultasif serta advokatif."16

14 Samiang Katu, "Penyuluh Agama Dan Pembumian Ajaran AlQur'an," 2015, 53-55.

15 Hasil Wawancara dengan H.RA.Qudus, Penyuluh Fungsional Kecamatan Ujungberung. Tanggal 19 januari 2018

16 Hasil Wawancara dengan Pak Fahmi , Penyuluh Fungsional Kecamatan Ujungberung. 
Pengalaman yang berbeda lagi disampaikan ibu kusfitriawati pengalaman dalam melaksanakan penyuluhan di Kecamatan Ujungberung, mengatakan bahwa:

"pengalaman saya selama diangkat 6 tahun sampai sekarang menjadi penyuluh, pak nandang ada 3 pengalaman dalam penyuluhan, pertama, masih banyak masyarakat belum tahu apa itu penyuluh, kedua, masih banyak masyarakat yang belum paham masalah nikah di kantor dengan nikah di rumah, ketiga, alhamdulillah sudah banyak Majlis taklim yang aktif dan kreatif."17

Berbeda-beda pendapat mengenai pengalaman dalam melaksanakan penyuluhan di Kecamatan Ujungberung, Hasil wawancara dengan Bapak Asep Sulaeman, bapak Yayat Sumirat, Bapak Kiki Murtakillah, meraka mengatakan bahwa:

"pengalaman saya selama diangkat 17 Tahun mendata majlis taklim sekecamatan Ujungberung, membantu keluhan majlis taklim yang disampaikan kepada kementrian agama kasi BIMAS, kalau pengalaman saya yayat sumirat 13 tahun jadi penyuluh sungguh luar biasa tantangan dalam penyuluhan dan juga mendata majlis taklim sekecamatan ujungberung dan masih banyak majlis takli yang kadang kosong pemateri, sama pendapat saya kiki 13 Tahun di angkat menjadi penyuluh dengan pak yayat. "18

Dapat peneliti simpulkan bahwa berbagai pengalaman dalam melaksanakan penyuluhan di Kecamatan Ujungberung dengan suka cita serta mendapatkan keilmuan yang mendalam dilapangan ketika melaksanakan penyuluhan dan juga masih ada masyarakat yang tidak mengetahui tentang penyuluh itu sendiri.

${ }^{17}$ Hasil Wawancara dengan Kusfitriawati, Penyuluh Fungsional Kecamatan Ujungberung.

18 Hasil Wawancara dengan Bapak Asep Suaeman,Bapak Yayat,Bapak Kiki, Penyuluh Fungsional Kecamatan Ujungberung. 


\section{Penyuluh Agama Islam di Kecamatan Ujungberung Kota Bandung menyampaiakan pesan dakwah melalui Tabligh}

Penyuluh Agama dalam melakukan pembinaan sesuai dengan tufoksinya. Fungsi pertaman yang dijalankan oleh Penyuluh Agama adalah melakukan fungsi informatif atau penyampaian pesan dakwah. Sasaran utama fungsi ini adalah Penyuluh Agama dituntut untuk mempromosikan dirinya sebagai orang atau pihak yang berkewajiban menyampaikan pesan-pesan dakwah ajaran Agama Islam dan membina masyarakat dengan sebaik-baiknya sesuai tuntunan Al-Qur'an dan As-Sunah.

Sebagaimana telah dijelaskan dalam Al-Qur'an surah AnNahl ayat 125:

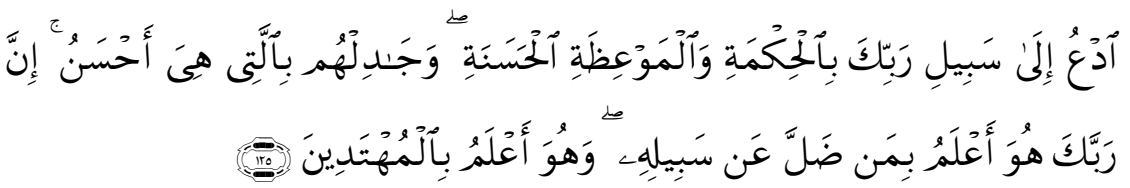

Artinya: Serulah (manusia) kepada jalan Tuhan-mu dengan hikmah dan pelajaran yang baik dan bantahlah mereka dengan cara yang baik. Sesungguhnya Tuhanmu Dialah yang lebih mengetahui tentang siapa yang tersesat dari jalan-Nya dan Dialah yang lebih mengetahui orang-orang yang mendapat petunjuk. ${ }^{19}$

Penyuluh agama Islam merupakan para juru dakwah yang diberi hak secara penuh oleh pejabat yang berwenang untuk melakukan kegiatan bimbingan atau penyuluhan agama islam terhadap masalah keimanan (aqidah) masalah keislaman (syari`ah) dan masalah budi pekerti (akhlakul karimah)". yang ada di Kecamatan Ujungberung. Kegiatan penyuluh agama Islam dilaksanakan di Kecamatan Ujungberung ini.

Untuk mencapai terwujudnya tugas dan fungsi serta pemyampaian pesan dakwah yang wajib dilakukan oleh Penyuluh Agama di Kecamatan Ujungberung, maka terdapat beberapa kegiatan dalam membina masyarakat Kecamatan Ujungberung serta dalam menyampaikan memalui tabligh.

19 Departemen Agama RI, Al-Qur'an dan Terjemahannya, (Jakarta:Syamil Cipta Media,2005),281. 
Berdasaekan hasil onservasi, wawancara dan dokumentasi di lapangan, bahwa diperoleh beberapa bentuk kegiatan dan penyampaian pesan dakwah di Kecamatan Ujungberung, yaitu diantaranya:

a. Bentuk-bentuk kegiatan penyuluh

Bentuk kegiatan penyuluhan yang dilakukan oleh Penuluh Agama Kecamatan Ujungberung dalam membina masyarakat sangan bervariasi sekali. Sesuai dengan konsep dasar Penyuluh Agama, yaitu Wad'u yang berarti penyampaian Ajaran Agama Islam atau pesan dakwah kepada masyarakat mengingat kondisi masyarakat yang multikultural beberapa kegiatan yang dilakukan dalam penyampaian pesan dakwah dan sessuai fungsi informatif di antaranya:

1) Majlis Taklim

Kegiatan majkis taklim yang dilakukan oleh penyuluh agama merupakan salah satu kegiatan rutin mingguan yang diberikan kepada masyarakat. Kegiatan majlis taklim ini biasanya dilaksanakan sesuai tugas masing-masing penyuluh di kelurahan yang berada di Kecamatan Ujungberung. Sebagaimana dikatakan oleh H.Drs.RA.Qudus bahwa:

Menurut hasil wawancara dengan Penyuluh Agama di Kecamatan Ujungberung, bahwa kegiatan majlis taklim dilakukan setiap hari dan mingguan serta sebulan sekali dengan bergiliran sesuai jadwal dan tugas yang sudah di tentukan di wilayah kelurahan masing-masing.

2) Majlis Taklim Konversi Diniyah (MTKD)

Kegiatan penyuluhan merupakan peran dan tugas utama Penyuluh Agama Islam. Beberpa bentuk kegiatan dalam penyampaian pesan melalui tabligh dengan cara penyampaian kepada ibu-ibu santri MTKD Al Ikhlas kecamatan Ujungberung ini merupakan tugas pokok dan utama. Sebagaimana tercantum dalam syarat penyuluhan Agama Islam yang ditentukan oleh Kasi BIMAS Islam. Ibu-ibu Majelis Taklim (MT) di Kecamatan Ujungberung Kota Bandung dibekali kurikulum dengan materi baca dan tulis Al-Qur'an. Sehingga mereka bisa menjadi guru baca dan tulis Alquran di lingkungannya masing-masing. 
Menurut Kusfitriawati selaku Penyuluh Fungsional Kecamatan Ujungberung menyatakan bahwa:

"Hancur dan majunya sebuah bangsa lahir dari seorang ibu. Untuk itu harus berinovasi agar kita menjadi bangsa juara, jika kegiatan MTKD tersebut akan berlangsung selama Tiga tahun dengan materi utama baca dan tulis Alquran. Selanjutnya peserta MT bisa menjadi guru di masjid atau rumahnya masing-masing." 20

Berikut gambar kegiatan santri Majlis Taklim Konversi Diniyah (MTKD) Kecamatan Ujungberung.

\section{Gambar 1}

\section{Kegiatan MTKD Al Ikhlas di Kecamatan Ujungberung}
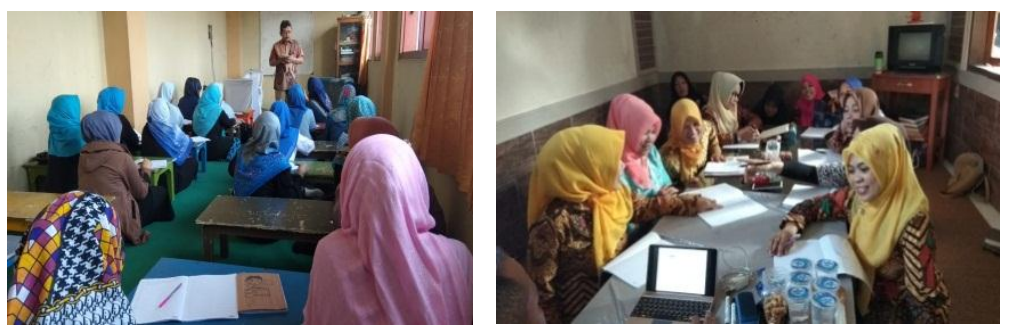

\section{3) Pelatihan}

Kegiatan pelatihan merupakan kegiatan yang dilakukan untuk memberikan tambahan wawasan dan ilmu pengetahuan kepada masyarakat. Bentuk kegiatan yang dilakukan di Kecamatan Ujungberung oleh Penyuluh Agama Islam terbagi menjadi dua bentuk kegiatan. Pertama, kegiatan pembinaan yang menyangkut keagamaan seperti fiqih, manasik haji. Kedua, kegiatan yang menyangkut sosial seperti manajemen masjid dan kesehatan.

Menurut Bapak Yayat Sumirat beberapa kegiatan pelatihan menyangkut keagamaan yang dilakukan yaitu,

"Pelatihan adalah salah satu program kegiatan tahunan yang ditargetkan untuk membina masyarakat Kecamatan Ujungberung. Pelatihan dilakukan dengan kerjasama antara Penyuluh Fungsional, KUA Kecamatan

${ }^{20}$ Hasil Wawancara dengan Kusfitriawati, Penyuluh Fungsional Kecamatan Ujungberung. Tanggal 19 januari 2018 
Ujungberung, Penyuluh Agama Honorer dan tokoh Agama di Kecamatan Ujungberung. Beberapa pelatihan yang pernah dilakukan adalah pelatihan Mengurus Jenazah, Pembinaan Pra Nikah dan Manajemen Masjid." 21

Sejalan dengan penrnyataan dari Bapak Fahmi selaku Penyuluh Agama Fungsional Kecamatan Ujungberung menuturkan,

“Bentuk kegiatan pelatihan yang menyangkut masalah fiqih merupakan kerjasama antara Penyuluh Agama Fungsional dengan Penyuluh Agama Honorer, ibu-ibu MTKD, Tokoh Masyarakat dan Trevel Haji dan Umroh. Bentuk kegiatan pelatihan yang dilakukan adalah Kegiatan Manasik Haji yang bertempat di Alun-Alun Kecamatan Ujungberung." 22

\section{4) Ceramah}

Ceramah adalah salah satu bentuk kompetensi dasar yang dimiliki oleh seorang Penyuluh Agama. Kegiatan ceramah, tausiyah, kultum atau sejenisnya merupakan suatu tugas yang diamanahkan kepada setiap penyuluh, tidak terkecuali penyuluh agama Islam dalam membina masyarakat Kecamatan Ujungberung. Sebagaimana Allah SWT telah menjelaskan dalam Al-Qur'an surah Al-Fusilat ayat 33 yaitu:

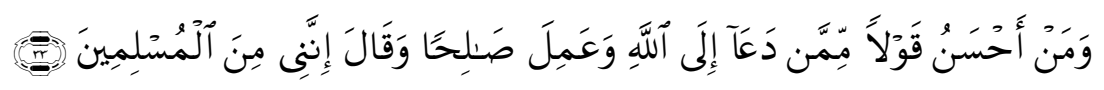

Artinya: "siapakah yang lebih baik perkataannya daripada orang yang menyeru kepada Allah, mengerjakan amal yang saleh, dan berkata: "Sesungguhnya aku Termasuk orang-orang yang menyerah diri." 23

Selain itu juga, sebagai seorang muslim yang wajib untuk menyampaikan nilai-nilai ajaran Agama Islam. Dakwah juga menjadi tugas dan kewajiban bagi setiap Penyuluh Agama Islam

21 Hasil Wawancara dengan Yayat Sumirat, Penyuluh Agama Honorer Kecamatan Ujungberung. Tanggal 20 januari 2018

22 Hasil Wawancara dengan Fahmi Ayatulloh, Penyuluh Fungsional Kecamatan Ujungberung. Tanggal 19 januari 2018

23 Departemen Agama RI, Al-Qur'an dan Terjemahannya,..487... 
di Kecamatan Ujungberung. Sebagaimana hasil wawancara dengan bapak Asep Sulaeman, mengatakan bahwa,

"kegiatan Ceramah bagi penyuluh Agama dalam penyampaian pesan dakwah adalah kegiatan rutinan yang dilakukan pada setiap acara pegajian ibu-ibu, peengajian remaja serta pada acara Peringatan Hari Besar Islam (PHBI) dan acara-acara sosial, seperti kesembatan acara Walimah urush atau Walimatus Shofar, Tasyakuran, Hajatan dan acara sosial lainnya." 24

5) Khutbah Jum'at

Khutbah jum'an merupakan salah satu kegiatan mingguan Penyuluh Agama Islam yang fungsional maupun yang Penyuluh Agama Honorer dalam membina masyarakat Kecamatan Ujungberung. Khutbah jum'at adalah cara cepat dan tepat bagi penyuluh untuk menyampaikan pesan dakwah melalui mimbar jum'at kepada masyarakat yang berada di Kecamatan ujungberung.

Mengingat kondisi masyarakat pada hari jum'at akan berkumpul dan jumlahnya lebih banyak dari hari lainya, maka penyampaian pesan dakwah yang menyangkut persoalan umum yang universal masyarakat disampaikan melalui mimbar jum'at oleh Penyuluh Agama sesuai tugasnya masing-masing kelurahan.

Menurut hasil wawancara dengan bapak H,Kiki Murtakillah selaku Penyuluh Agama Honorer Kecamatan Ujungberung menuturkan bahwa,

"Kegiatan penyampaian pesan dakwah melalui mimbar Khutbah jum'at ini dilakukan oleh Penyuluh Agama bekerjasama dengan KUA Kecamatan, Para DKM dan Tokoh Masyarakat setempat. Tempat yang digunakan untuk shalat jum'at di Kecamatan Ujungberung terdiri dari 5 Kelurahan yang telah di tugaskan untuk mengisi jadwal khutbah jum'at. "25

${ }^{24}$ Hasil Wawancara dengan Asep Sulaeman, Penyuluh Agama Honorer Kecamatan Ujungberung. Tanggal 28 januari 2018

25 Hasil Wawancara dengan H. Kiki Murtakilah, Penyuluh Agama Honorer Kecamatan Ujungberung. Tanggal 25 januari 2018 
b. Pesan Dakwah Tentang Moderasi Beragama Yang Disampaikan Melalui Tabligh Dalam Kegiatan Penyuluhan

Peran dan tugas Penyuluh Agama Islam pada hakikanya adalah menyampaikan dan membantu individu untuk mengetahui, mengenal dan memehami kembali tentang diri sendiri dan fitrahnya. Beberapa pesan dakwah yang disampaikan dalam penyuluhan oleh Penyuluh Agama kepada masyarakat Kecamatan Ujungberung bertujuan untuk menginformasikan dan mendidik masyarakat. Menurut hasil wawancara dan observasi di lapangan, sesuai dengan fungsi informatif pesanpesan yang disampaikan oleh Penyuluh Agama diantaranya yaitu:

\section{1) Aqidah}

Pesan aqidah adalah pesan mengenalkan masyarakat kepada penciptanya yaitu Alloh SWT. Menurut Ida Nurfarida beberapa pesan yang disampaikan dalam kegiatan Majlis Taklim, MTKD, Ceramah adalah "mengenal tentang nama-namanya, sifat -sifatnya, penciptaannya dan zatnya." 26 Pesan mengenal Tuhan ini disebut dengan Ilmu Tauhid. Sebagaimana Firma Alloh dalam Al-Qur'an suah Al-Baqarah ayat 163, yaitu:

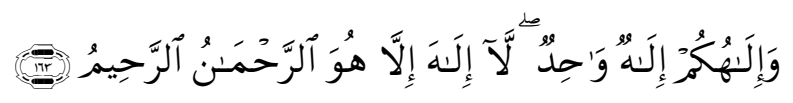

Artinya: "Dan Tuhanmu adalah Tuhan yang Maha Esa; tidak ada Tuhan melainkan Dia yang Maha Pemurah lagi Maha Penyayang." 27

Lilis Rohmatul Hasanah menambahkan tentang akhlak ini bahwa Ilmu Tauhid atau bisa disebut Ilmu mengenal Tuhan ini terbagi menjadi 3 bagian diantaranya sebagai berikut:

"Tauhid Uluhiyah, Tauhid Rububiyah dan Tauhid Asma wa Sifa." 28

26 Hasil Wawancara dengan Ida Nurfarida, Penyuluh Agama Honorer Kecamatan Ujungberung. Tanggal 25 januari 2018

27 Departemen Agama RI, Al-Qur'an dan Terjemahannya,..23...

${ }^{28}$ Hasil Wawancara dengan Lilis Rohmatul Hasanah, Penyuluh Agama Honorer Kecamatan Ujungberung. Tanggal 25 januari 2018 
Tauhid Uluhiyah adalah ilmu mengenal Tuhan bahwa tiada yang berhak disembah kecuali Alloh SWT, dan Alloh SWT adalah yang Maha Esa.

Tauhid Rububiyah yaitu Ilmu mengenal Alloh SWT bahwa tiada ciptaan di alam semesta ini melainkan Milik Nya keMaha Kuasaannya. Tauhid Asma wa Sifa yaitu Ilmu mengenalkan kepada masyarakat tentang Tuhannya bahwa Alloh SWT adalah Rabbul Alamin (Tuhan yang mengatur seluruh alam), yang maha aziz (Perkasa), Hakim (Bijaksana), As-Ma'i (maha Mendengar), Al - Bashar (Maha Melihat), Ar-rahman dan Ar-rahiim ( Maha Pengasih dan Maha Penyayang) dan nama-nama sifat-sifat Alloh yang dlainnya.

2) Akhlak

Akhlak merupakan persoalan yang menyangkut budi pekerti atau prilaku manusia dengan Tuhannya, manusia dengan sesama manusis dan manusia dengan lingkungannya. Pesan dakwah dalam kegiatan penyuluhan yang dilakukan oleh Penyuluh Agama Islam di daerah Kecamatan Ujungberung diantaranya adalah tentang moral. Akhlak terhadap Allah dan rasulnyam akhlak terhadap orang tua, adab membaca Al-Qur'an, akhlak dalam keluarga dan Etik bergaul dengan Masyarakat.

Menurut Nia Yuniarti materi tentang Akhlak ini adalah "mengajarkan masyarakat tentang menjaga hubungan baik dengan sesama musilm dan juga dengan Non Muslim, terutama dalam hubungan bertentangan atau dengan kata lain Habuminannas." Kemudian Nia Yuniati juga menambahkan bahwa "Masyarakat Muslim adalah masyarakat yang toleran." 29

Menurut Nia Yulianti, mengambil beberpa ayat yang dijadikan dasar dalam menyampaikan materi diantaranya Q.Surah Ali Imran ayat 134:

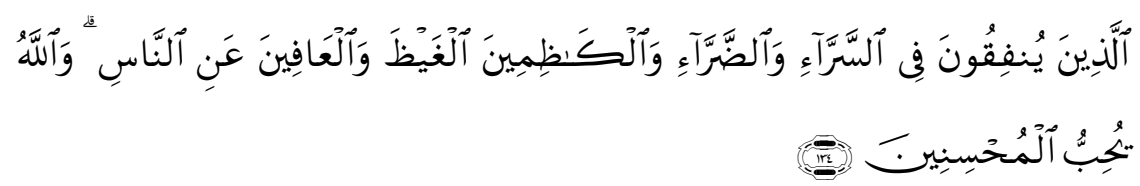

${ }^{29}$ Hasil Wawancara dengan Nia Yulianti Hamidah, Penyuluh Agama Honorer Kecamatan Ujungberung. Tanggal 25 januari 2018 
Artinya: "(yaitu) orang-orang yang menafkahkan (hartanya), baik di waktu lapang maupun sempit, dan orang-orang yang menahan amarahnya dan mema'afkan (kesalahan) orang. Allah menyukai orang-orang yang berbuat kebajikan". ${ }^{30}$

3) Fiqih

Secara harfiyah fiqih artinya ilmu tentang hukum. Hukum yang dinaksudkan adalah hukum menyangkut masalah Ibadah, Munakahat, Muamalah, dan Mawaris. Menurut hasil wawancara dan observasi hasil di lapangan pesan dakwah yang disampaikan melalui tabligh oleh Penyuluh Agama terkait hukum terdiri dari beberapa hal. Diantaranya yaitu,

Menurut Hj.Imas Kurniasih materi fiqih yang disampaikan dalam kegiatan Majlis Taklim, MTKD, Pengajian adalah,

"Hukum tentang shalat, baik shalat fardhu lima waktu maupun shalat sunnat, fadhilah shalat, keutamaan shalat berjamaah, hukum shalat munfarid, dan hukum yang menyangkut permasalahan shalat." 31

Menurut bapak Yayat Sumirat materi yang disampaikan dalam pelatihan di antaranya adalah "Hukum tentang penyelenggaraan Shalat Jenazaah dan permasalahan masyarakat." Begitu juga dengan bapak Fahmi, , Ayi Latife, bahwa materi yang sering disampaikan adalah,

"materi yang disampaikan ada umumnya adalah berbicara tentang menukah dengan berbeda agama dan permasalahan yang berkaitan dengan pernikahan, hukum Haji dan Umrah, hukum Jual beli kepada Orang Non Muslim, Hukum ijab qobul dalam jual beli dan utang piutang, hukum tentang ahli waris orang tua muslim dan anak Non Muslim (ataupun sebaliknya)." 32

4) Cinta Tanah Air atau Nasionalisme

Cinta Tanah Air adalah materi atau pesan dakwah yang disampaikan oleh penyuluh Agama Islam dalam membina

30 Departemen Agama RI, Al-Qur'an dan Terjemahannya,..87..

${ }^{31}$ Hasil Wawancara dengan Hj.Imas Kurniasih , Penyuluh Agama Honorer Kecamatan Ujungberung. Tanggal 4 Februari 2018

32 Hasil Wawancara dengan Bapak yayat, Bapak Fahmi ,Bapak Ayi 
masyarakat Kecamatan Ujungberung. Pesan tabligh tentang Cinta Tanah Air ini sering disampaikan dalam bentuk Khutbah Jum'at dan ceramah-ceramah. Sebagaimana hasil wawancara dengan bapak Asep Sulaeman, menyebutkan bahwa:

"Pesan dakwah yang disampaikan tentang Cinta Tanah Air ini sesuai dengan hadits Rasulullah yaitu Hubbul Waton minal iman artinya Cinta tanah Air sebagaian dari Iman. Maka untuk menyampaikan materi Nasionalisme ini kami para penyuluh Agama sering bekerja sama dengan pihak kepolosian dan aparatur pemerintahan setempat. Terkadng sebgai Khotib menyampaikan Khutbah Jum'at, terkadang juga mengisi di acara taklim dan pengajian. Materi ini pernah disampaikan adalah "Menjaga Keutuhan NKRI."33

c. Media yang digunakan dalam menyampaikan pesan dakwah melalui tabligh

Media merupakan suatu sarana dan alat yang digunakan oleh Penyuluh Agama untuk menyampaikan pesan-pesan keagamaan dalam kegiatan penyuluhan. Beberapa media yang digunakan oleh para penyuluh agama di Kecamatan Ujungberung dalam membina dan menyampaikan pesan dakwah diantaranya al-Qur'an, Kitab-kitab Hadis, bukubuku,slide, infocus.laptop, proyektor.

Bentuk media yang digunakan oleh Penyuluh Agama dalam menyampaikan pesan-pesan dakwah atau materi penyuluhan terkait dengan Aqidah,Akhlak,fiqih, sesuai dengan bentuk kegiatan seperti Majlis Taklim, khutbah dan Ceramah adalah dengan menggunaan Al-Qur'an, kitab-kitab Hadis dan Kitab Ulama, buku-buku keagamaan. Sedangkan media untuk menyampaikan pesan dakwah melalui materi Pelatihan,pengajian bulanan dan MTKD menggunakan sound system, proyektor. Laptop, infokus dan Papan tulis.

33 Hasil Wawancara dengan Bapak Asep Sulaeman, Penyuluh Agama Honorer Kecamatan Ujungberung. Tanggal 20 Januari 2018 
d. Bentuk Komunikasi Dakwah dalam kegiatan Penyampaian Pesan Dakwah

Bentuk komunikasi dakwah adalah jenih komunikasi yang disampaikan oleh para Penyuluh Agama Islam dalam membina Masyarakan Ujungberung. Bentuk komunikasi dakwah ini digunakan sesuai dengan bentuk kegiatan yang dilakukan dan media yang digunakan dalam penyampain pesan dakwah.

Bentuk komunikasi dakwah yang digunakan oleh Para Penyuluh Agama Islam dalam menjalankan memberikan pesan dakwah melalui tabligh dan menjalankan fungsi informatif di daerah Kecamatan Ujungberung terdiri dari:

1) Komunikasi Personal

Bentuk komunikasi personal ini yang digunakan penyuluh Agama Islam dalam menyampaikan pesan dakwah kepada masyarakat Ujungberung sesuai fungsi informatif adalah melalui kegiatan MTKD, Khutbah, Ceramah.

2) Komunikasi Kelompok

Bentuk komunikasi kelompok yang digunakan oleh Penyuluh Agama Islam dalam menyampaikan pesan dakwah melalui tabligh kepada masyarakat Kecamatan Ujungberung dilakukan melalui kegiatan Pelatihan, Majlis Taklim dan Pengajian.

3) Komunikasi Massa

Komunikasi massa ini adalah bentuk komunikasi melalui media massa. Bentuk komunikasi yang digunakan oleh Penyuluh Agama Islam dalam membina dan menyampaikan pesan dakwah kepada masyarakat Kecamatan Ujungberung dengan meggunakan media cetak. Bentuk komunikasi massa ini yang digunakan adalah dalam bentuk brosur atau pengumuman pentung seputar informasi sosial keagamaan.

\section{Interaksi penyuluh Agama Islam di Kecamatan Ujungberung dengan masyarakat dalam proses penyuluhan}

Dalam berinteraksi dengan sesama seharusnya kita melihat dan memperhatikan dengan siapa kita berinteraksi, agar normanorma yang ada tidak kita langgar sehingga interaksi yang kita 
jalani berjalan dengan baik, begitu pula berinteraksi antar agama ada norma-norma yang harus dijaga memperhatikan bagianbagian yang boleh dilakukan dan tidak boleh dilakukan. Beberapa hal yang perlu di perhatiakan dalam berinteraksi antara lain ego, kepekaan, jujur dan terbuka, humoris dan rendah hati dan jadi diri sendiri.

Secara teorotis sekurang-kurangnya ada dua syarat bagi terjadinya interaksi sosial, yaitu terjadinya kontak sosial dan komunikasi. Terjadinya suatu kontak sosial tidaklah semata-mata tergantung dari tindakan, tetapi juga tergantung kepada adanya tanggapan terhadap tindakan tersebut. Sedangkan aspek terpenting dari komunikasi adalah bila seseorang memberikan tafsiran pada sesuatu perikelakukan orang lain.

a. Praktek Interaksi Sosial

Interaksi sosoial adalah suatu hubungan antara dua individu atau lebih dimana kelakuan individu yang satu mempengaruhi, mengubah atau memperbaiki kekuatan individu yang lain atau sebaliknya sehingga terjadi proses sosial. Cirinya adanya pelaku yang berjumlah lebih dari satu orang, terjalin komunikasi yang aktif diantara para pelaku, adanya maksud dan tujuan yang jelas dari interaksi tersebut dan biasanya dilakukan dalam suatu pola tertentu. Jenis interaksi sosial dibedakan menjadi tiga yaitu interaksi sosial antar individu, interaksi sosial antara individu dengan kelompok dan interaksi sosial antara kelompok dengan kelompok.

Penyuluh Agama Islam Kecamatan Ujungberung selalu memebrikan arahan dalam pelaksanaan penyuluhan sehingga respon masyarakat terhadap kegiatan penyuluhan relatif berbeda. Dari hasil wawancara dengan Bapak Fahmi Ayatulloh mengatakan bahwa:

b. Silaturahmi

Dalam Islam, interaksi sosial berarti hubungan sosial. Bentuk hubungan yang populer dalam Islam yaitu silaturrahim. Yang artinya hubungan kasih sayang. Silaturrahim sebagai bentuk interaksi sosial dilakukan pada kegiatan Masjlis Taklim dan Kegiatan MTKD, menyambut bulan suci ramadhan serta bersilaturahmi safari dakwah ke majlis taklim yang belum tersentuh oleh penyuluh. 
Silaturahmi adalah kegiatan yang dilakukan oleh penyuluh Agama Kecamatan Ujungberung dengan cara berkunjung ke masyarakat atau sebaliknya masyarakat yang berkunjung ke kantor penyuluh agama. Interaksi dilakukan di beberapa tempat dengan cara bertatap muka antara penyuluh Agama dengan Masyarakat.

\section{c. Interaksi dakam kegiatan Ekonomi}

Untuk memenuhi semua kebutuhannya, manusia harus bekerja. Manusia bekerja sesuai dengan kondisi wilayah tempat tinggalnya, pendidikan maupun sesuai bakat keterampilannya. Dalam kehidupan sehari-hari tidak seorangpun dapat membuat barang yang dibutuhkannya. Oleh sebab itu harus ada kerjasama antara orang yang satu dengan yang lainnya, kerjasama itu saling melengkapi. Ada yang bekerja sebagai petani memproduksi bahan pangan, ada yang membuat pakaian untuk dijual atau diperdagangkan dan seterusnya. Kegiatan ekonomi ini pun sudah dicontohkan oleh nabi Muhammad SAW, pada zamannya nabi Muhammad menjalin kerjasama perdagangan dengan bangsa selain agama Islam seperti bangsa Romawi, Persia, dan sebagainya. Selain misi berdagang Nabi pun berdakwah memperluas, menyebarkan agama Islam dan mempererat jalinan persaudaraan dengan agama lain.

Sebagai contoh kecil dari manfaat kegiatan ekonomi dikehidupan bermasyarakat sekitar, warung kopi dapat mempertemukan orang-orang dari berbagai etnis dan agama, tidak secara fisik melainkan juga pemikiran, ide, dan perasaan. Sisi lain yang membuat warga menjadi akrab selain kegiatan mengobrol diwarung kopi adalah kebiasaan untuk membayar minuman orang lain. Kerukunan umat beragama akan dapat tercipta secara alamiah jika dibangun diatas fondasi yang konkrit, saling berbagi dan melayani.

\section{Kesimpulan}

Setelah dilakukan penelitian secara cermat, maka hasil penelitian ini berkesimpulan bahwa:

1. Pengalaman Penyuluh Agama Islam di Kecamatan Ujungberung dalam melaksanakan penyuluhan tentang moderasi beragama dengan berbagai suka cita serta 
mendapatkan keilmuan yang mendalam dilapangan ketika melaksanakan penyuluhan dan juga masih ada masyarakat yang tidak mengetahui tentang penyuluh itu sendiri. Serta dalam melaksanakan penyuluhan di Kecamatan Ujungberung tidak terlepas dari tugas pokok dan fungsi penyuluh untuk melaksanakan dan mengembangkan kegiatan bimbingan dengan fungsi penyuluh sebagai informatif dan edukatif, konsultatif serta advokatif.

2. Penyuluh Agama Islam dalam menyampaikan pesan dakwah melalui tabligh di Kecamatan Ujungberung ini tinjau dari beberapa aspek diantaranya: Pertama, ditinjau dari bentuk kegiatan yang dilakukan oleh penyuluh Agama Islam di Kecamatan Ujungberung, sesuai dengan fungsi informatif dan edukatif bentuk kegiatan penyuluhan yang dilakukan, terdiri dari Majlis Taklim, MTKD, Pelatihan, Khutbah Jum'at dan Ceramah. Kedua, ditinjau dari jenis pesan yang disampaikan sesuai dengan bentuk kegiatan penyuluhan yang dilakukan. Jenis-jenis pesan yang disampaikan dalam kegiatan menyampaikan pesan dakwah melalui tabligh ini diantaranya pesan Aqidah, Akhlak, Fiqih, dan Cinta Tanah Air atau bahasa lain di sebut Nasionalisme. Ketiga, ditinjau dari yang digunakan dalam menyampaikan pesan dakwah dalam kegiatan penyuluhan. Media yang digunakan oleh para penyuluh terdiri dari media cetak, media tulis dan media elektronik. Media ceta terdiri dari Al-Qur'an, Kitabkitab Hadits, Buku-buku keagamaan dan media cetak lainnya seperti selembaran atau brosur.

3. Penyuluh Agama Islam dalam berinteraksi dengan masyarakat yang berada di Kecamatan Ujungberung dengan bersilaturahmi dengan kelompok Majlis Taklim, MTKD dan masyarakat sekitar. Sedangkan pesan yang disampaikan dalam kegiatan bimbingan dan konseling tidak terlepas dari tiga aspek yaitu, aqidah, syariah, fiqih dan muamalah. Media yang digunakan dalam berinteraksi dalam penyuluhan bersifat langsung, karena komunikasi yang digunakan juga sifatnya personal. Kecuali kegiatan yang bersifat kelompok yaitu konsultasi di KUA, masjid dan tempat pertemuan lainnya. 


\section{Daftar Pustaka}

Alsa, Asmadi. Penelitian Psikologi. II. Yogyakarta: Pustaka Pelajar Offset, 2004.

Andrian, Bob. "KOMUNIKASI KONSULTATIF PENYULUH AGAMA ISLAM DI DAERAH PERBATASAN KALIMANTAN BARAT." Jurnal Bimbingan Penyuluhan Islam 1, no. 2 (January 11, 2020): 251. https:// doi.org/10.32332/jbpi.v1i2.1717.

"Data Kependudukan: Dinas Kependudukan dan Catatan Sipil Kota Bandung:Tahun 2016)." DUKCAPIL KOTA BANDUNG, 2016.

Fahri, Mohamad, and Ahmad Zainuri. "Moderasi Beragama di Indonesia" 25, no. 2 (2019): 6. https://doi.org/DOI: doi.org/10.19109/intizar.v25i2.5640.

“Https:/ /Www.Republika.Co.Id/Berita/Dunia-Islam/IslamNusantara/19/05/20/Prscm7320-Pentingnya-

Memaksimalkan-4-Tugas-Pokok-Penyuluh-Agama," n.d.

Jamil, Abdul. "Penyuluhan Agama Islam Dan Problema Keislaman Kontemporer." In SEMINAR, 4. LABDA Fakultas Dakwah Dan Komunikasi IAIN Walisongo, n.d.

Katu, Samiang. "Penyuluh Agama Dan Pembumian Ajaran AlQur'an," 2015, 21.

Khotimah, Husnul. "INTERNALISASI MODERASI BERAGAMA DALAM KURIKULUM PESANTREN." Rabbani: Jurnal Pendidikan Agama Islam 1, no. 1 (January 27, 2020): 62. https:// doi.org/10.19105/rjpai.v1i1.3008.

Mubarok, Ahmad. Konseling Agama: Teori dan kasus. 1st ed. Vol. 1. JAKARTA: PT Bina Rena Parwira, 2002.

Mubarok, Ahmad Agis, and Diaz Gandara Rustam. "ISLAM NUSANTARA: MODERASI ISLAM DI INDONESIA." Journal of Islamic Studies and Humanities, 2018, 16. https:// doi.org/DOI:

http://dx.doi.org/10.21580/jish.32.3160. 
Muhtadi Saeful, Asep. Bandung Agamis Landasan, Pendekatan, Indikasi dan program Aksi,. 1st ed. 1. Sekretariat Daerah Kota Bandung, 2009.

“Paradigma Interpretatif.Htm,” n.d.

“Profil Laporan Tahunan KUA Ujungburung, Tahun 2016.” KUA Ujungberung, 2016.

Sugiyono. Metode Penelitian Pendidikan; Pendekatan Kuantitatif, Kualitatif, Dan RED. III. Bandung: Alfabeta, 2010. 